\title{
Rail integrated communities in Tokyo
}

\section{John Calimente}

Stantec, Inc. ${ }^{\text {a }}$

\begin{abstract}
Tokyo's railway station areas are models of transit-oriented design. To differentiate them from transit-oriented developments (TOD), the term rail integrated community (RIC) has been created to describe these high density, safe, mixed-use, pedestrian-friendly developments around railway stations that act as community hubs, are served by frequent, all-day, rail rapid transit, and are accessed primarily on foot, by bicycle, or by public transit. Japanese private railway operators have been instrumental in creating these RICs. Though they receive little financial support from the government, private railways in Japan operate profitably by diversifying into real estate, retail, and numerous other businesses. Tokyu Corporation is used as the case study to exemplify how government policy and socioeconomic context contributed to the successful private railway model. Ten indicators, such as ridership, population density, and mode share are used to analyze two stations created by Tokyu to demonstrate how this model is manifested in Tokyu's rail integrated communities.
\end{abstract}

Keywords: Value capture; Tokyo; Urban rail; Transit-oriented development; TOD; Private railways; Rail integrated communities; RIC

\section{Introduction}

Could the average North American imagine life without their car?

For the vast majority of those who grew up in North America after the Second World War, the automobile has become the primary mode of transportation. While some may give up the comfort of their vehicle to commute by public transit, most other journeys, regardless of distance, are completed by car. For a trip to visit friends, to the mall, to the local gym, or to a nearby town, for most people the automobile seems to be the only viable option. Yet in metropolitan Tokyo these activities are all easily accessible by train at almost any time of the day. Railways are a vital component of the transportation network in the city, and remarkably for the twenty-first century, the private railways in Tokyo Metropolis operate at a profit.

In their attempts to increase ridership and thereby generate greater profits, these private railways have created high density, mixed-use, pedestrian-friendly developments around railway stations that act as community hubs; are served by frequent, all-day, rail rapid transit; and are accessed primarily on foot, by bicycle, or by public transit. We have created the term rail integrated community (RIC) to differentiate these devel-

\footnotetext{
a Transit planner and founder of Rail Integrated Developments. jcali-
} mente@gmail.com opments from the concept of transit-oriented development (TOD) that originated in North America.

Is there something unique about Japanese society that has created RICs? While cultural factors do play a role, we demonstrate that a combination of government policy, socioeconomic factors, and innovation by the private railways gave rise to these communities. Japan's private rail operators were originally forced by the nationalization of their trunk railway lines in the early twentieth century to look beyond railway operations for profits. By the time the automobile began its rise in Japan in the mid-1960s, Tokyo's dense rail network and its station area communities were already well established. Government regulation of fares coupled with limited subsidies for railway operations pushed the private railways to innovate and diversify into a wide variety of related businesses, most notably real estate. Due to their long-term interest in the communities they built along their rail lines, the private railways provided valuable social benefits through public transportation while still pursuing profits. High quality, frequent rail service to dense, mixed-use, safe, pedestrian-friendly developments has allowed Tokyo to achieve enviable rates of public transit usage and given Tokyoites the freedom to view automobile ownership as a lifestyle choice rather than a necessity.

Tokyu Corporation, one of the first private railways to achieve success through diversification into related businesses, is used as the case study. Two successful RICs created by

Copyright 2012 John Calimente.

Licensed under the Creative Commons Attribution - NonCommercial License 3.0. 
Tokyu, Jiyugaoka and Tama Plaza, are measured on ten indicators to show how differently they function from North American TODs.

\section{Methods}

This study used a multi-method approach, with data gathered from books, journal and magazine articles, statistical databases, and email questionnaires. Research was conducted at the National Diet Library, through interviews with Tokyu Corporation staff, by photographing and documenting Jiyugaoka and Tama Plaza stations, and by meeting with planning staff from Setagaya Ward ${ }^{1}$ Office. Numerous Japaneselanguage books, websites, and reports were referenced to develop a more detailed understanding of RICs in Tokyo.

In order to build the case for RICs and provide a more detailed picture of how the Tokyo transit model works on the ground, Tokyu Corporation (Tokyo Kyuko Dentetsu Kabushiki-gaisha) has been used as a case study of the private railway model in Japan in its most successful form. Two stations, Jiyugaoka and Tama Plaza, were selected to be analyzed on a set of ten indicators to demonstrate the difference between rail integrated communities (RICs) in Tokyo and the transit oriented developments (TODs) commonly developed in North America.

\section{Transit-oriented developments in North}

\section{America}

Transit-Oriented Developments (TOD) are defined by Dittmar and Ohland $(2004,4)$ as "...mixed use, walkable, location-efficient developments that balance the need for sufficient density to support convenient transit service with the scale of the adjacent community." (Bernick and Cervero $1996,5)$ extend this idea in their transit village concept, “...a compact, mixed-use community, centered around the transit station that, by design, invites residents, workers, and shoppers to drive their cars less and ride mass transit more." The radius of the transit village is about 500 meters from the station, or a little over five minutes on foot (Vuchic 2005).

While TODs themselves are usually walkable, they are often not complete communities that provide jobs, schools, services, retail, entertainment, and recreation. Some of these developments go by the term transit-proximate development or transit-adjacent development (TAD), to identify them as

\footnotetext{
${ }^{1}$ Setagaya Ward is one of the 23 wards of Central Tokyo and the location of Jiyugaoka Station.
}

walkable communities that contain some features that encourage public transit use. For those living in these North American TODs and TADs, particularly in suburban communities, the underlying assumption seems to be that residents may commute to work by public transit, but will use their cars for most other tasks, including getting to and from the station.

Suburban TODs often include large parking lots so that residents can go directly to their cars as soon as they reach their station. Outside of working hours, frequency of transit service drops significantly, making it unlikely that transit will be used by discretionary riders who have their own vehicles. Even riders who would like to walk or bike home are dissuaded from doing so by unattractive, desolate and often unsafe station areas that lack any shops or services, access roads without sidewalks or bike paths, and the long distances involved as a result of single-use zoning that separates shops and services from residences. Furthermore, these TODs are usually missing the morning-to-night vibrancy that is produced when a wide range of uses come together in an area with greater population density and lower automobile usage.

Although TODs in North American suburbs may increase transit usage to some extent, in their current form they are not likely to greatly reduce automobile dependence. Truly successful developments near public transit need to be based on the idea that those living in such a community should easily be able to conduct all of their daily business using public transit, by bicycle, and on foot. This means that the transit system, as well as the surrounding neighborhoods, must easily accommodate those without an automobile. This is not what is currently being built in most of North America.

\section{Tokyo and its station area developments}

A better model for mixed-use station area developments can be found in Tokyo, Japan, which has been building them for over 100 years. The city has one of the most heavily used rail networks in the world, providing frequent, all-day service to the central city and also within the suburbs. The urban villages surrounding the stations provide riders for the system, as well as being destinations in and of themselves. These areas are invariably mixed-use, with stores, schools and universities, government offices, housing, restaurants, and bars all located within walking distance from the stations.

It is somewhat surprising that a metropolitan area with a total population of 35.7 million (United Nations 2007) in which less than 30 percent of residents commute by automobile (Japanese Ministry of Land, Infrastructure, Transport and Tourism 1999) has received comparatively little attention for 
its station area developments. Research to date has been overwhelmingly focused on the United States, Canada, Australia, or the countries of Western Europe. Perhaps this is due to a perception that Japanese society is fundamentally different from that of other countries, leading to an assumption that successes in Japan cannot be replicated elsewhere. Or it may be simply due to the general tendency of researchers to look at countries with which they are familiar. In any case, much can be learned from the way that private railway companies in Japan have been able to maintain consistent profitability, something unheard of for most other transit operators, save for a few agencies like the Hong Kong MTR subway. ${ }^{2}$

\subsection{Tokyo: Population and transportation}

Tokyo Metropolis (Tokyo-to) has a population of 12.9 million stretched across the 23 wards $^{3}$ of Central Tokyo and 26 suburban municipalities of the Tama area ${ }^{4}$ that cover the western half of the city (Tokyo Metropolitan Government 2009). The 23 wards make up the original city of Tokyo, and hold a population of 8.75 million, or 68 percent of the total (Fig. 1). The commuting zone is much larger, stretching out to a radius of about $50 \mathrm{~km}$ from the center of the city, a total area of $10117 \mathrm{~km}^{2}$. Called the Tokyo Metropolitan Area (TMA) or Shutoken, ${ }^{5}$ it holds 35.7 million people (United Nations 2007), more than the population of Canada. ${ }^{6}$ It is the largest urban agglomeration in the world (City Mayors Statistics 2005), spreading over the prefectures (administrative districts) of Tokyo, Kanagawa in the southwest, Chiba in the east, and Saitama in the north, as well as parts of other neighboring prefectures. The TMA accounts for a full 28 percent of Japan's population and 28 percent of its GDP (City Mayors Statistics 2005) while covering only 3.5 percent of the land area of Japan (Morichi 2000, 611).

Tokyo has one of the highest rates of transit usage in the world. In terms of modal split, 25.5 percent of the population of Tokyo Metropolis in 1998 used the train as their primary means of transportation (City of Yokohama Urban Development Bureau 1998). This figure increases to 41.5 percent for Tokyo's 23 wards (Ibid). A full 71 percent of commuters in

\footnotetext{
${ }^{2}$ Net profits for the Hong Kong MTR subway in 2007 were HK\$8.57 billion (US\$1.1 billion). Fare revenue was 66.6 percent of overall revenue (MTR Corporation 2008).

${ }^{3}$ In Japanese, the 23 wards are called either Tokyo-to Kubu, Tokubetsu $K u b u$ (special wards), or Tokyo 23-ku (Tokyo 23 wards). In this study they will be referred to as the 23 wards.

${ }^{4}$ In Japanese Tama Chiiki, Tama Chiku, or San-Tama.

${ }^{5}$ Other names are Tokyo-ken and Tokyo Toshi-ken.

${ }^{6}$ Canada's population in October 2008 was estimated at 33.4 million (Statistics Canada 2008).
}

Tokyo Metropolis take the train, increasing to 91 percent of commuters bound for the 23 wards (Ieda 1995). Automobiles represent 33.2 percent of mode share for Tokyo Metropolis, but only 15.3 percent in the 23 wards. Both walking and cycling have high mode shares, at 14.5 percent and 22.3 percent, respectively, in Tokyo Metropolis and 14.9 percent and 23.8 percent in the 23 wards (Ibid).

\subsection{Factors that prevent reliance on the automobile}

Jones $(1983,6)$ found that there is ".... fundamentally different attitude toward car ownership and use...” in Japan. He determined the factors to be:

- A tradition of restricting mobility by road during the Tokugawa rule up to 1868 , and the subsequent limited rate of growth of the road network in comparison with some other industrialized countries

- Good public transit

- The regulation that car owners must own or rent a parking space for their vehicle ${ }^{7}$, coupled with the high cost of land that raises the price of these spaces ${ }^{8}$

- On-street parking is very limited in most cities, and employers don't generally provide free parking ${ }^{9}$

- The time and expense of obtaining a driver's licence ${ }^{10}$

- Payment of commuting expenses by employers, but generally only for public transit, not private car

In Tokyo, one has to be prepared to spend a great deal of money to purchase and own an automobile, which contributes to the popularity of public transit in the city. Cervero (1998) states that the Japanese government imposes strict controls on automobile ownership because of Japan's limited land area and lack of domestic oil reserves. Vehicle taxes include “...a commodity tax on manufacturers and three taxes on purchasers: a

\footnotetext{
${ }^{7}$ Car owners must prove they own a parking space before they can buy a car, unless the car is less than $3.4 \mathrm{~m}$ long with an engine no larger than 660 cc (Colliers International 2008).

${ }^{8}$ As recently as 2004 , the average monthly charge for condominium parking was $¥ 24250$ (US\$250/€195) in Tokyo Metropolis and ¥19 175 (US\$195/€155) in the TMA (Hosono 2004).

9 The average monthly cost for pay parking lots in Tokyo Metropolis in 2008 was $¥ 49000$ (US\$500/€395) (Colliers International 2008).

${ }^{10}$ Japanese drivers must pass written, practical, and physical (eye exam, etc.) tests to receive their driver's license. It is usually necessary to attend a driving school to pass the practical test, where courses typically cost at least $¥ 300000$ (US\$3075/€2425) (Fukuoka International Association 2006).
} 


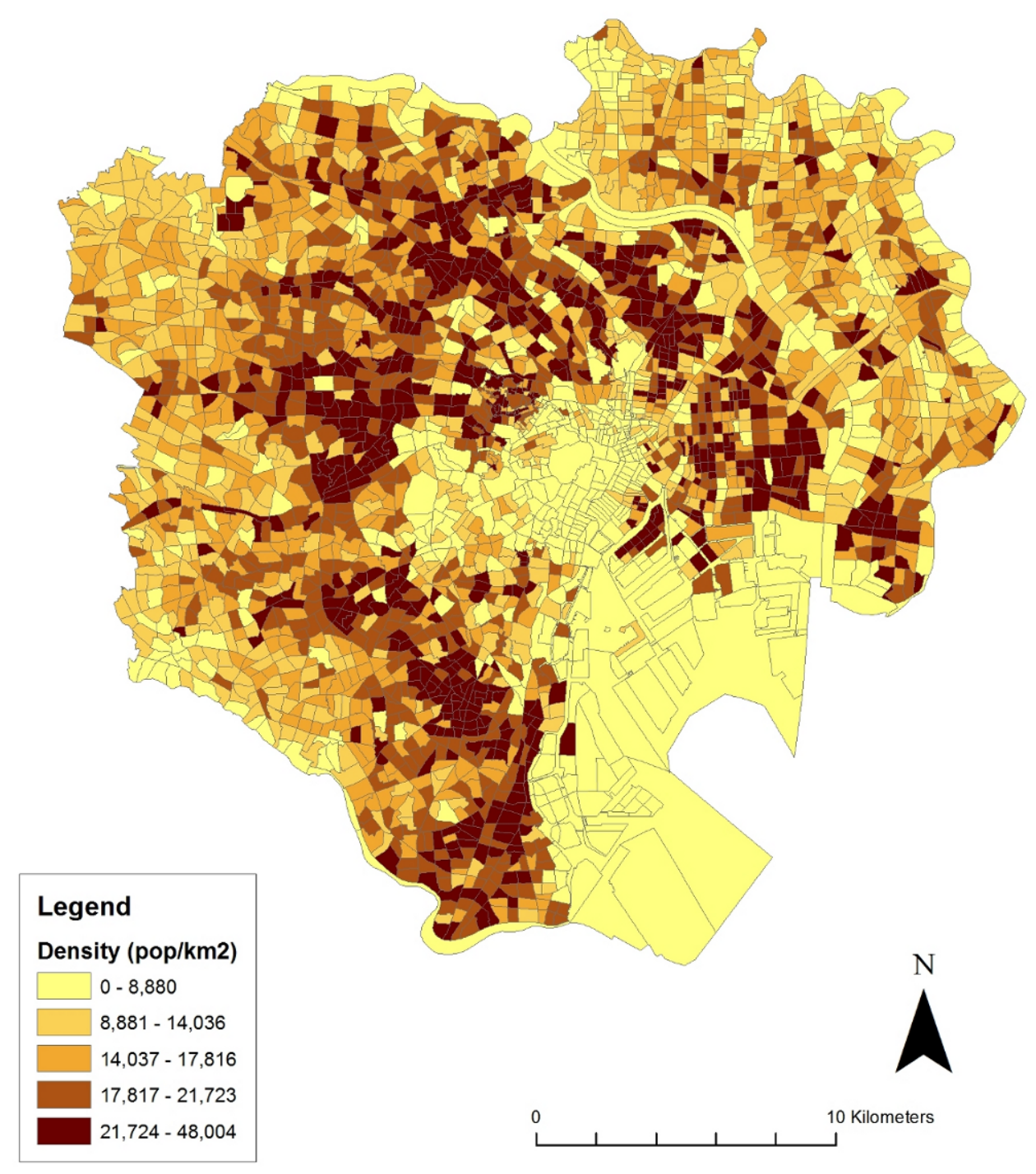

Figure 1: Population density in Central Tokyo. Map showing the density in each of the census tracts in the 23 wards of Central Tokyo. Source: Nakamura (2010); data from Official Statistics of Japan 
vehicle acquisition (excise) tax, an annual automobile (registration) tax, and a surcharge based on vehicle weight." In addition, gasoline taxes are two to three times those of North America, with the price of gasoline per liter US $\$ 1.26^{11}$ versus US\$0.54 in the United States and US\$0.68 in Canada (Victoria Transport Policy Institute 2006). There is also a mandatory vehicle inspection program called the sha-ken ${ }^{12}$ for vehicles with engine capacities greater than $250 \mathrm{cc}$. This is conducted every year to two years at a cost of between $¥ 49000$ to $¥ 150000$ (US\$490-1500; €370-1125) each time, depending on the vehicle type and use (Japanese Ministry of Land, Infrastructure, Transport and Tourism 2002).

Further, all expressways in Tokyo are toll roads (Cervero 1998). And while Japan has now caught up to the rest of the world in terms of freeway building, ${ }^{13}$ Japan's expressway tolls are among the highest in the world, about double those of European countries. ${ }^{14}$ If we average the total cost of buying a new car, as well as gasoline, taxes, and inspection fees over nine years, it works out to $¥ 50000$ (US\$500, €400) per month, or $¥ 600000$ (US\$6000, €4600) per year in a country where many employees make ¥3-4 million per year ${ }^{15}$ (Railway Town Development Conference 2004). These factors have meant that only 64 million people, about half the population, hold driver's licenses (Asano 1998).

\subsection{Rail integrated communities (RICs)}

In Japanese metropolitan areas like Tokyo, automobile ownership is not essential, since all aspects of daily life can be conducted by taking a train, bus, bicycle, or travelling on foot. Employment, entertainment, shopping, and government services cluster around train stations, rendering the private automobile almost unnecessary in many parts of the city. Population densities, ridership, and transit mode share are high, property values increase with proximity to the station, land uses are mixed, the access to the station is usually either on foot or by bicycle, automobile parking is limited but bicycle parking is plentiful, and the transit system has a high quality

\footnotetext{
${ }^{11}$ Average gasoline prices in Japan are closer to European countries like Spain (US\$1.21) and Ireland (US\$1.29) (Victoria Transport Policy Institute 2006).

${ }^{12}$ Formally, the jidousha kensa touroku seido (Automobile inspection registration system).

${ }^{13}$ In 2005, Japan had $0.058 \mathrm{~km}$ of freeway per person, about the same as the United Kingdom (0.059). Germany had more than double this amount (0.146) while the United States had 0.253 freeway-km per person (Japan Road Association 2005).

${ }^{14}$ Tolls in Japan average $¥ 25$ (US\$0.25, €0.19) per km, compared with $¥ 11$ per $\mathrm{km}$ in France and $¥ 7$ per km in Italy (Nagata 2008).

${ }_{15}$ This works out to an automobile costing roughly $15-20 \%$ of total wages per year.
}

and frequency of service from early morning until late at night. Train stations are the centers of life for the surrounding communities.

Since these station area developments are so fundamentally different from the TODs in North America, the term rail integrated community, or RIC, has been created. Rail integrated communities are defined as high density, safe, mixeduse, pedestrian-friendly developments around railway stations that act as community hubs, served by frequent, all-day, rail rapid transit that is accessed primarily on foot, by bicycle, or by public transit. A well-functioning RIC requires not only attention to the physical form when constructing the station and surrounding neighbourhoods, but also the creation of government policies that allow the transit service provider to thrive over the long term through funding sources other than the farebox. The Japanese private railways that have built most of these RICs have adopted forward-thinking strategies to not only build ridership but also develop other revenue streams. The railways receive revenue through fares and also create revenue through other means such as real estate development, retail sales, advertising, and other ancillary businesses such as travel agencies. These profits then help to provide increased and expanded service for their riders.

\section{Japan's private railways}

Private railways have played a vital role in creating in Japan one of the world's densest railway networks. In a country that has firmly embraced the automobile, the continued success of private railways stems from a combination of government policy and entrepreneurial spirit that pioneered a strategy of diversification into mutually supportive, related groups of companies.

Japan's first railway opened in 1872, built by the Japanese government using British technology to run steam engines between Tokyo and Yokohama. Japan Railway (Nihon Tetsudo), the first private railway in Japan, was founded in 1883 (Mizutani 1994). While the growth of the interurban railway network was tepid for the next 10 years, construction boomed in the latter half of the 1880s, and by 1900 the network extended to most areas of Japan (Fujita and Hill 1993). As early as 1893, Japan had $3010 \mathrm{~km}$ of railways, of which $2125 \mathrm{~km}$ were private and $885 \mathrm{~km}$ were government-owned (Aoki et al. 2000).

However, rail as a means of intraurban transport didn't take off until the advent of electric streetcars at the turn of the twentieth century. Three private companies opened lines between 1903 and 1904, amalgamating into a company called the Tokyo Railway, which was eventually bought by the Tokyo 
municipal government in 1911 (Arisue and Aoki 1970). Also around this time, private railway companies began operating suburban streetcar lines, mainly on the west side of the city.

In March 1906, the national government passed the Railway Nationalization Act (Tetsudo Kokuyu-ho), nationalizing 17 of the 37 existing private railways between 1906 and 1907, and electrifying these lines over the next few years (Aoki 1994). Its purpose was to "...smooth domestic transport, cut freight tariffs and passenger fares, and standardize and integrate railway infrastructure" (Aoki et al. 2000, 40). It had the added goals of making it possible to issue foreign bonds that could be mortgaged against railway assets, and of preventing foreigners from holding shares in the railways (Aoki et al. 2000). Just prior to nationalization, private railways had represented 68 percent of all rail trackage in the $\operatorname{country}^{16}$ (Ibid), so this had a severe impact on the private railway operators, who under law could only build railway lines that weren't in competition with government lines:

(Private railway operators) were thus compelled to serve areas with small populations. While private companies anticipated that rail operations could be self-supporting, the limited customer base forced them to 'generate' ridership through business diversification (Shoji 2001, p. 15).

What might been a death blow to the private railways turned out to be a blessing in disguise. Because they were forced to diversify into other areas, particularly real estate, operators did not remain wholly dependent on fares for revenue. Using a diversification strategy pioneered by Ichizo Kobayashi, the president of Osaka's Hanshin Electric Railway, private railway companies in Osaka and Tokyo began developing and selling residential land along their train lines, constructing and operating department stores at terminal stations, as well as building tourist attractions along their routes. Residential growth fuelled by the private railway developments on the western side of Tokyo in the 1920s and early 1930s caused traffic to concentrate at the terminal stations on the Yamanote Line, ${ }^{17}$ especially Shibuya, Shinjuku, and Ikebukuro stations (Fig. 2). This was the start of their new role as sub-centers of the original Nihombashi business district, initiating the polycentric city structure that now makes up Tokyo. Two of the railway operators on Tokyo's west side, the Meguro-Kamata ("Mekama") and Tokyo-Yokohama

\footnotetext{
${ }^{16}$ Private railways totalled $5213 \mathrm{~km}$ while government railways covered $2413 \mathrm{~km}$ (Aoki et al. 2000).

${ }_{17}$ The Yamanote Line is the major loop line that circles central Tokyo, connecting many of Tokyo's major stations. One loop takes about one hour.
}

(“Toyoko") railways, were also real estate developers (Arisue and Aoki 1970, 198) that eventually merged to form Tokyu Corporation, whose history is dealt with below.

The private railways were able to survive and thrive by branching out into businesses closely connected with the railway industry, while private operators in Europe and North America slowly began to fail due to increased competition from the automobile. Unlike the bankruptcy-hit railway operators in most other countries, many of the original private railway companies are still the biggest players in the Japanese railway industry today (Shoji 2001).

\section{Tokyu corporation}

Tokyu Corporation is one of 16 major private railway operators in Japan and one of the first companies to create master planned developments around its train stations. It was established as a regional development company in 1922 and has since grown to become Japan's largest rail-based conglomerate with a total of 390 companies and nine foundations (Cervero 1998), employing about 30000 people, of which 3400 work directly for the railway (Tokyu Corporation 2007). While the real estate, retail, and tourism businesses seek to bring passengers into stations, “....activities such as construction, design, and engineering have sought to capitalize on and expand the domain of the railroad companies' labor forces" (Cervero 1998, 190).

The company began life as Meguro-Kamata Dentetsu, the railway division of the Den-en Toshi (Garden City) Corporation, a development and real estate company (Oshima 1996). The corporation was founded by developer Eiichi Shibusawa, publishing magnate Tsuneta Yano, and a group of influential businessmen to build Den-en Chofu, the first Garden City in Japan. Den-en Chofu was built between 1922 and 1926 on the Garden City model of Ebenezer Howard (Miyata 1995). The Den-en Toshi Corporation bought large tracts of land for development prior to laying the rail lines (Cervero 1998), in a location 30 minutes to the west of Tokyo.

Sales were very slow initially, but the company had an unlikely saviour in the Great Kanto Earthquake of 1923 (Kiriyama 1997). With the center of the city burned out, the suburbs suddenly became very appealing, and Den-en Chofu quickly became one of the most prestigious residential areas in Japan (Cervero 1998). Meguro-Kamata Dentetsu, led by president Keito Goto, took over the Den-en Toshi Corporation as well as a number of other railways, continuing to build numerous rail integrated communities throughout the 1930s (Ibid). 


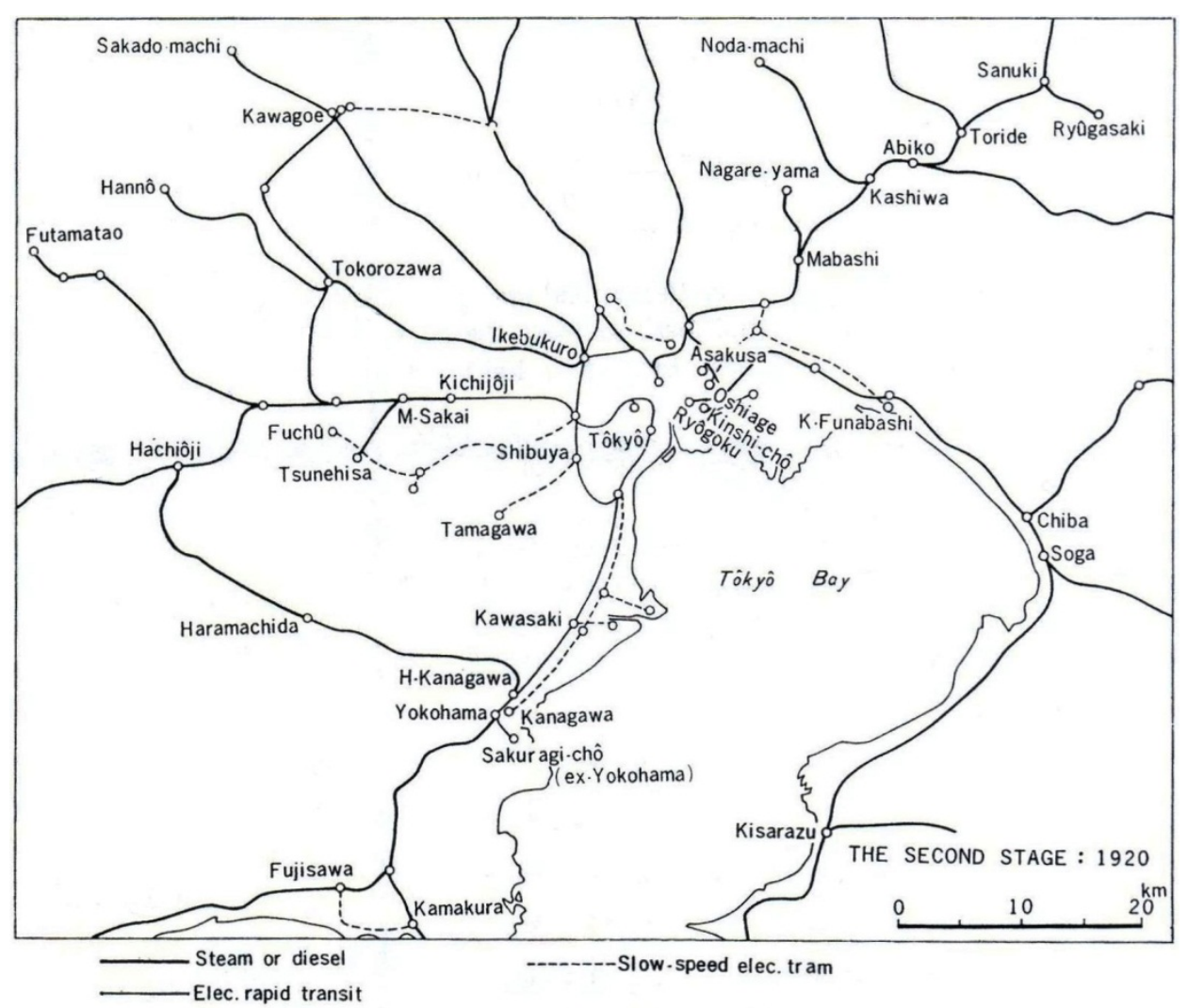

Figure 2: The Tokyo railway network in 1920. Source: Arisue and Aoki $(1970,193)$.

While Tokyu Corporation had adopted its diversification strategy from Ichizo Kobayashi, the president of Hanshin Electric Railway, Goto's innovation was to attract universities and other educational institutions from the urban center to suburban locations near its stations (Kato 1996). On the Toyoko line, for example, Tokyu built high rise commercial centers at Shibuya station in Tokyo at one end and Sakuragicho station in Yokohama at the other, and opened its first department store near Shibuya in 1934 (Cervero 1998). The corporation offered land at low rates to universities and schools in order for them to build campuses at intermediate stations along the way. The commercial hubs and the universities "...have produced a steady bidirectional flow of passengers, ensuring efficient train operations” (Cervero 1998).

Tokyu Corporation now has seven main lines and one small branch line (Fig. 3) and its rail network is mostly free from competition from other lines, except for several JR East lines that cross Tokyu rail lines from north to south. Because the rail lines are relatively short, the rail trips are also short, which has produced the highest ridership and farebox returns per $\mathrm{km}$ of track of all the private railways (Cervero 1998).
Although it is only the thirteenth-largest railway network in Japan, Tokyu's network carries the most passengers of any of the private railways ${ }^{18}$ (Ibid). In 2006, its 2.79 million riders per day gave it the highest average daily ridership of any of the suburban railway companies, bested only by the Tokyo Metro and JR East (Japanese Ministry of Land, Infrastructure, Transport and Tourism (2005a); Tokyu Corporation (2007)). Ridership was 1.02 billion passengers in 2006 (Association of Japanese Private Railways 2007).

Tokyu is one of the most profitable railway operators in the country, with net profits of $¥ 58.72$ billion (US\$587 million, $€ 441$ million) on operating revenues of $¥ 263.7$ billion (US\$2.63 billion, €1.98 billion) in 2006 (Tokyu Corporation 2007). Real estate and transportation each bring in an equal share $(33.5 \%)$ of net profit, with the rest coming from retail $(20.2 \%)$ and other sources.

\footnotetext{
${ }_{18}$ The top five Japanese private railways by yearly ridership in 2006: Tokyu, Tobu (855 million); Odakyu (689 million); Hankyu (618 million);, and Keio (613 million) (Tokyu Corporation 2007).
} 


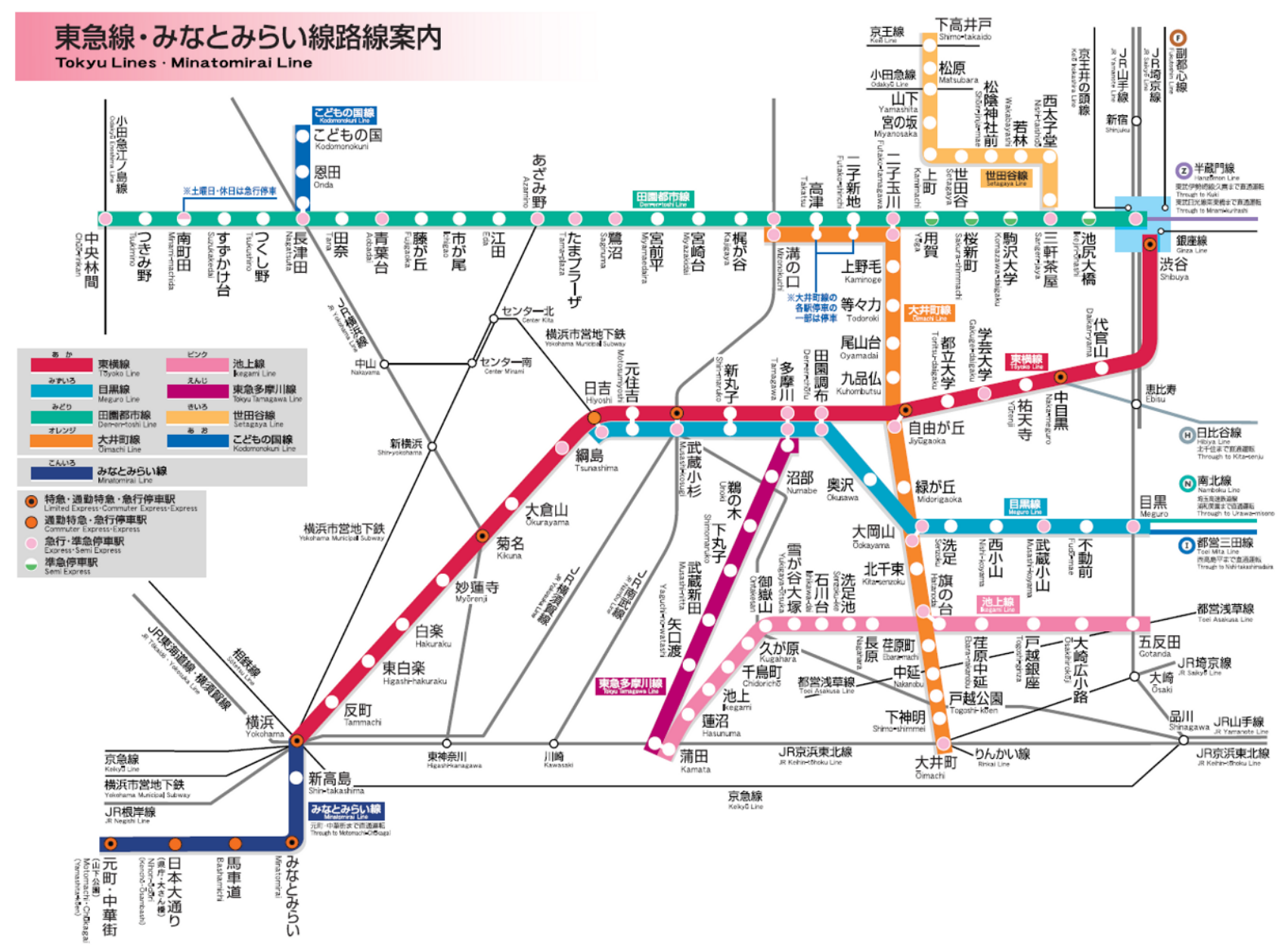

Figure 3: Tokyu railway route network. The Toyoko Line (red) connects Yokohama station in the bottom left with Shibuya station in the upper right. Den-en-toshi Line (green) and Toyoko Line converge at Shibuya station. Other major Tokyu lines are the Oimachi Line (orange), the Tamagawa Line (purple), the Meguro Line (light blue), and the Ikegami Line (pink). Source: (Tokyu Corporation 2011).

\section{Indicators for rail integrated communities}

The continuous process of refinement of the RIC concept in major Japanese cities by private railways means that insights should be gained from analyzing long-standing RICs that cannot be gained from analyzing newly created ones. In order to demonstrate how different rail integrated communities (RICs) in Tokyo are from the transit oriented developments (TODs) commonly developed in North America, two station area developments in Tokyo (Jiyugaoka and Tama Plaza) were surveyed using a series of ten indicators. By rating TODs on an integrated set of indicators, they can be systematically measured, evaluated, and monitored to determine their success and ultimately compared with TODs in other countries.

\subsection{Choice of indicators}

The indicators chosen for this analysis were:

1. Transit Ridership (boardings, alightings, and through passengers)

2. Quality of service (frequency, hours of service, passenger load, and commuter pass cost)

3. Mode share (primary means of transportation \& between home and train station)

4. Number of mode connections

5. Number of parking spaces (bicycle and automobile)

6. Density (housing density and population density) 
7. Property values within and beyond $500 \mathrm{~m}$ of the station

8. Quality of streetscape design

9. Pedestrian safety (per capita death rate)

10. Crime rate (per 1000 people)

Six of the indicators were adapted from the list of Suggestions for Evaluating TODs, prescribed in a report titled Transit-Oriented Development: Developing a Strategy to Measure Success (Transportation Research Board 2005) published by the Transportation Research Board's National Cooperative Highway Research Program: Transit ridership, number of mode connections, number of parking spaces, density (housing density and population density), quality of streetscape design, and pedestrian safety.

The indicator increases in property value and tax revenue is used for examining new TODs, but since the two stations in the case study are not new developments, property values within and beyond 500 meters of the station were substituted. Although the indicator number of parking spaces in the TRB report refers exclusively to automobile parking, counts for bicycle parking have also been added since more commuters bike to train stations in Tokyo than drive (Japanese Ministry of Land, Infrastructure, Transport and Tourism 2005b). The transit ridership indicator was included to supplement data on boardings and alightings.

Four additional indicators were added to capture empirically some of the unique characteristics of RICs. In order to include a performance measure of transit that reflects the passenger's point of view (as opposed to vehicle-focused performance measures), as well as demonstrate the high quality of rail service in Tokyo, a quality of service indicator based on the Quality of Service Framework created by the Transportation Research Board will be used (Transportation Research Board 2003). Commuter pass cost has also been added as a service measure to facilitate cost comparisons with other transit systems.

Mode share was also used as an indicator, since data for Tokyo is readily available, and the Transportation Research Board has recommended indicators to help quantify "...not only localized outcomes (of TODs) but also regional impacts on traffic congestion and air quality..." (Transportation Research Board 2005). Finally, crime rate within the ward where the station is located has been added as an indicator, as safety concerns are one of the most important reasons why passengers in North America don't ride transit, especially in large cities (Hartgen et al. 1993). The relationship between crime and ridership is more complicated than can be identified in this study; it is plausible that overall lower crime rates in Japanese cities encourage transit ridership, and that higher ridership in turn contributes to lower crime rates. Certainly the indicators point to low crime rates in the station precincts.

\subsection{Jiyugaoka and Tama Plaza Stations}

While noting that there is little individuality among Tokyo's suburban towns, (Kawasaki 1993) singles out Jiyugaoka and Tama Plaza stations (as well as Shimokitazawa and Kichijoji) as having a distinct character owing to their formal planning and development by Tokyu Corporation. Of the four stations singled out by Kawasaki, only Jiyugaoka and Tama Plaza were developed and are serviced exclusively by a single private railway company.

These stations and their surrounding areas were analyzed qualitatively and quantitatively using indicators developed by the (Transportation Research Board 2005). Area coverage is normally computed as the area within a five-minute walk or a $400 \mathrm{~m}$ radius of a railway station, but since station buildings usually spread out $100 \mathrm{~m}$ or more, area coverage for rail systems is often expanded to a $500 \mathrm{~m}$ radius (Vuchic 2005). As a result, the latter figure has been used for this analysis.

\section{Jiyugaoka Station}

Jiyugaoka station is located at the southern end of Meguro ward, one of the Tokyo 23 wards, and is close to both central Tokyo and the City of Yokohama. It is six stations away from Shibuya station on the Toyoko line and 14 stations away from Yokohama station to the west, as can be seen in Fig. 4.

In a 2007 survey, Jiyugaoka was ranked second behind Kichijoji as the most desirable place to live in Tokyo, and was particularly popular with housewives and men over 50 (Home's Club 2007). Reasons given were its quiet location somewhat removed from the central city, secure environment, sophisticated image and the numerous appealing shops and services (Ibid). Jiyugaoka also ranked second in a survey by real estate developer Haseko Urbest, cited for its green spaces, quiet residential areas, walkability, and easy access to fashionable shops and services (Haseko Urbest Inc 2007).

\section{Tama Plaza Station}

Tama Plaza station is situated in the northwest corner of the City of Yokohama, eight stations from the border with Tokyo Metropolis and 19 minutes away from Shibuya station by express train (Tokyu Corporation, 2009).

Prior to the opening of the Tokyu Den-en-toshi line in 1966 , the area was mostly fields, with only one small shopping 


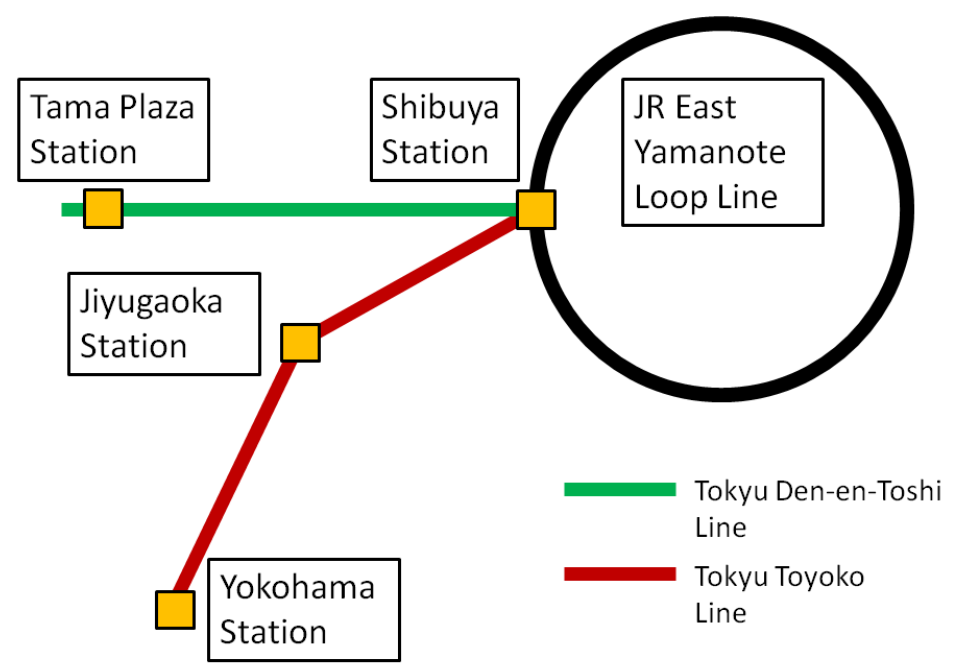

Figure 4: Locations of Jiyugaoka and Tama Plaza stations. Stations are shown in relation to Shibuya station to the east on the Yamanote Loop Line in central Tokyo, with Yokohama station to the southwest.

street (Tamapura Scope 2007). Tama Plaza station was constructed as part of Tokyu Corporation's massive Tama Denen Toshi development, built on a 4300 ha stretch of the Tama hills across the four cities of Kawasaki, Yokohama, Yamato, and Machida City in Tokyo (Keiei Jōhō Center 1971). Planning began in 1953 and construction started in 1966 with the opening of the Den-en-toshi line (Ibid).

\section{Important indicator findings}

In this section, important indicator findings will be highlighted, while a summary of all indicators can be found in Tables 1, 2 and 3. One significant result was the extremely high percentage of commuters who walk to each of the stations to board trains: 71 percent at Jiyugaoka station and 57 percent at Tama Plaza station. On the other hand, those travelling by car, motorbike, or taxi only made up 5 percent of those destined for Jiyugaoka station and 11 percent for Tama Plaza (Ministry of Land, Infrastructure, and Transport, 2005). Undoubtedly one reason for the low percentage of commuters driving to stations is the low number of parking spaces in the vicinity of the stations. Within $500 \mathrm{~m}$ of Jiyugaoka station there are 70 automobile parking lots with a total of 569 spaces (S-Park 2008). Most of these lots are very small, with the largest having only 120 spaces, and the station has no officially designated parkand-ride lot. There are a total of 776 parking spaces for automobiles within $500 \mathrm{~m}$ of Tama Plaza station (Goo Housing and Real Estate 2008). There is little on-street parking in the station areas, and where it exists, parking is limited to only a few hours.

Tokyu Coporation can offer a very high quality of transit service due to the high ridership created by the dense communities surrounding the station, as well as the schools, businesses, and government facilities that draw people from other parts of the region. Trains serving both Jiyugaoka and Tama Plaza stations run approximately 20 hours per day, seven days a week. Time between departures averages 2.5 minutes in the morning peak period, three minutes in the evening peak period and three to five minutes during off-peak periods and on weekends.

Another finding was the high population density within $500 \mathrm{~m}$ of the stations. The seven zones surveyed that surround Jiyugaoka station had a total population of 19063 people, with a population density of 12808 persons per $\mathrm{km}^{2}$. The five zones around Tama Plaza station had a population of 24004 , giving a population density of 13046 persons per $\mathrm{km}^{2}$ (Tokyo Metropolitan Government 2009). However, one negative effect of the high population density and intensity of land uses near the stations is the high cost of real estate, which also results in increased rental costs. Housing prices ${ }^{19}$ in the area less than a five-minute walk from Jiyugaoka station were about double those around Tama Plaza station, at $¥ 1375900$ (US $\$ 13650, € 10065$ ) per $\mathrm{m}^{2}$ versus $¥ 697500$ (US\$6920, €5105) per $\mathrm{m}^{2}$ (Beans-Coop 2009). It is important to note, however, that residents of a RIC can forgo owning an automobile and the high yearly operational costs associated with it.

${ }^{19}$ Prices were converted from $t$ subo to square meters. One $t s u b o=3.3 \mathrm{~m}^{2}$. 
Table 1: Ridership and quality of service, Jiyugaoka and Tama Plaza stations.

\begin{tabular}{llll}
\hline RIC Indicators & \multicolumn{3}{c}{ Location } \\
\hline Ridership at station & $\begin{array}{l}\text { Jiyugaoka } \\
\text { (Toyoko Line) }\end{array}$ & $\begin{array}{l}\text { Jiyugaoka } \\
\text { (Oimachi Line) }\end{array}$ & $\begin{array}{l}\text { Tama Plaza } \\
\text { (Den-en-toshi line) }\end{array}$ \\
\cline { 2 - 4 } $\begin{array}{l}\text { Average daily boardings } \\
\text { Average daily alightings }\end{array}$ & 105045 & 81392 & 42444 \\
Average daily through passengers & 108218 & 80191 & 42600 \\
& 477146 & 207368 & 390918 \\
Commuting & Setagaya ward & Meguro ward & Aoba ward \\
Percentage of riders commuting to the 23 wards & $82.10 \%$ & $85.80 \%$ & $65.00 \%$ \\
Percentage of riders commuting within the ward & $2.80 \%$ & $1.30 \%$ & $3.50 \%$ \\
Average commute time (minutes) & 55 & 50 & 70 \\
Average monthly commuter pass cost to Shibuya station (¥) & 12167 & 10731 & 14533 \\
Quality of service & & & \\
Frequency & Toyoko Line & Oimachi Line & Den-en-toshi Line \\
$\quad$ Morning peak hours (trains per direction per hour) & & & \\
$\quad$ Off-peak hours (trains per direction per hour) & 25 & 20 & 26 \\
$\quad \begin{array}{l}\text { Hours of service } \\
\text { Hours of service per day (weekday) }\end{array}$ Hours of service per day (weekend) & 18 & 12 & 12 \\
Crowding & & & 19.47 \\
$\quad$ Passenger load (peak \%) & 19.67 & 19.5 & 19.47 \\
\hline
\end{tabular}

Table 2: Mode share, mode connections, and parking spaces, Jiyugaoka and Tama Plaza stations.

\begin{tabular}{lll}
\hline RIC Indicators & $\begin{array}{l}\text { Jiyugaoka station } \\
\text { (Setagaya and Meguro wards) }\end{array}$ & $\begin{array}{l}\text { Tama Plaza station } \\
\text { (Aoba ward) }\end{array}$ \\
\hline Mode share: To and from station (\%) & & 0.572 \\
$\quad$ Walk & 0.705 & 0.292 \\
$\quad$ Automobile or other motor vehicle & 0.045 & 0.026 \\
$\quad$ Cycle & 0.118 & 0.11 \\
Bus & 0.132 & 6 \\
Mode connections (number of bus routes from station) & 3 & 776 \\
Parking spaces within 500m of station & & 665 \\
$\quad$ Number of automobile spaces & 569 & 673 \\
$\quad$ Number of bicycle spaces & & \\
\hline
\end{tabular}


Table 3: Population, development, property values , pedestrian safety, and crime rate indicators, Jiyugaoka and Tama Plaza station areas.

\begin{tabular}{|c|c|c|c|c|c|c|c|c|c|}
\hline $\begin{array}{l}\text { RIC indicators for } \\
\text { Jiyugaoka and Tama Plaza }\end{array}$ & $\begin{array}{l}\text { Setagaya } \\
\text { ward }\end{array}$ & $\begin{array}{l}\text { Meguro } \\
\text { ward }\end{array}$ & $\begin{array}{l}\text { Jiyugaoka } \\
\text { station area }\end{array}$ & $\begin{array}{l}\text { Tama Plaza } \\
\text { station area }\end{array}$ & $\begin{array}{l}\text { Aoba } \\
\text { ward }\end{array}$ & $\begin{array}{l}\text { City of } \\
\text { Yokohama }\end{array}$ & Tokyo 23 & $\begin{array}{l}\text { Tokyo } \\
\text { Metro }\end{array}$ & Japan \\
\hline Population density (Persons $/ \mathrm{km}^{2}$ ) & 14841 & 18282 & 12808 & 13046 & 8577 & 8402 & 14057 & 5894 & 329 \\
\hline Persons per household & 1.93 & 1.83 & 1.85 & 2.26 & 2.41 & 2.34 & & & \\
\hline Dwellings per hectare & 73.2 & 100.1 & 69.2 & 57.8 & 35.4 & 35.8 & & & \\
\hline \multicolumn{10}{|l|}{ Property values $\left(¥ / \mathbf{m}^{2}\right)$} \\
\hline$<500 \mathrm{~m}$ from station (under $5 \mathrm{~min}$. walk) & & & 1375900 & 697500 & & & & & \\
\hline$>500 \mathrm{~m}$ from station ( $5-10 \mathrm{~min}$. walk) & & & 947700 & 537000 & & & & & \\
\hline$>500 \mathrm{~m}$ from station (10-15 min. walk) & & & 854700 & 445000 & & & & & \\
\hline$>500 \mathrm{~m}$ from station ( $15-20 \mathrm{~min}$. walk) & & & & 862300 & 424900 & & & & \\
\hline $\begin{array}{l}\text { Pedestrian safety (Death rate from traffic } \\
\text { accidents per } 100000 \text { people) }\end{array}$ & & & 0 & & 1.69 & 2.4 & & 0.61 & 5.78 \\
\hline Crime rate (incidents per 1000 people) & 14.43 & 13.81 & & & 7.01 & & & & 19.2 \\
\hline
\end{tabular}

The RIC indicators for Jiyugaoka and Tama Plaza stations provide a snapshot of communities with population densities, transit ridership, transit mode share, and quality of transit service higher than the vast majority of North American communities. It is possible these indicators could shift in the future if the increasing rate of private vehicle ownership in Japan impacts the Tokyo area to a greater degree. In addition, the high rates of transit usage found in this study do not necessarily hold true across the whole region; population density and transit mode share generally decrease as the distance from central Tokyo increases. Finally, not all station areas in Tokyo are created alike. Many are not as well planned and designed as Jiyugaoka, Tama Plaza, and other stations developed by Tokyu Corporation.

\section{Conclusions and further research}

Due to the early nationalization of main trunk lines by the national government, private railways in Japan needed to develop methods of increasing ridership and creating alternate sources of revenue. By adopting an innovative business diversification strategy, railways such as Tokyu were better able to adapt to the impact of car culture when it eventually arrived in Japan in the mid- to late 1960s. Favorable market conditions (densely populated cities with concentrated urban cores) and national government policies and regulations that support public transit and discourage car ownership have improved rail profitability. The national government has also made driving an expensive proposition, while at the same time subsidizing commuter passes and regulating fare increases. As a result, the mode share for walking, cycling, and transit is greater than for driving and the Tokyo region enjoys "....arguably the most sustainable pattern of regional development among any of the world's megacities" (Cervero 1998, 206).

Importantly, the connection between land use and transportation has been strengthened due to the large role that real estate development plays in the profitability of the railways. Rail integrated communities have been the result of this approach: dense, livable, mixed-use centers that also provide the transit riders that help make the railways profitable. These riders are also customers of the myriad businesses that Japanese private railways like Tokyu Corporation engage in. This diversified approach to the railway business has allowed private railway companies in Japan to build the stable ridership needed to survive and thrive.

The ten indicators used in this study have shown just how different RICs such as Jiyugaoka and Tama Plaza are from North American TODs. Since these station areas have each had at least 40 years to densify and solidify their ridership base, it would be instructive to also look at historical indicators to see how quickly this took place, especially when planning RICs in the future. The indicator work presented in this report could also provide a benchmark for studies of RICs in Tokyo and other Japanese cities. A further step in this research would be to compare the policy history and business model of Tokyu Corporation with that of successful RICs in other countries.

As has been seen recently, the high cost of fuel has helped create record ridership for North American transit systems, but ironically it also impacts their budgets, with many US systems considering fare increases or service cuts (Mieszkowski 
2008). A spokeswoman for the American Public Transit Association president has noted that "...we don't have the funding to expand public transportation systems" (Ibid, 1). Public transportation systems that rely solely on revenue from fares topped up by public funding are limited in their ability to provide quality service with existing vehicles and infrastructure, much less to expand. And while transit agencies could potentially finance their operating costs through fare revenue, “... social and political objectives often drive the fare" (Anderson 2006, 24).

Rather than relying strictly on farebox revenue and taxation, transit agencies in North America should be freed to develop other revenue sources, just as the Japanese private railways have done to great success. Diversification into related businesses could hold the key to long term financial health for public transit in North America. Above all, real estate development holds great promise if transit agencies can either capture a portion of land price increases generated by extending rail lines, or develop land around existing stations that is currently underutilized. A version of the rail integrated community model developed in Tokyo could be a key to greater financial stability for public transit in North America.

\section{References}

Anderson, R. 2006. Metro benchmarking yield tangible results. ERO: Energy Regulatory Office monthly report. URL http://www3.imperial.ac.uk/pls/portallive/docs/1/ 8595697.PDF.

Aoki, E. 1994. Expansion of railway network. Japan Railway \& Transport Review, 2:34-37. URL http://www.jrtr.net/ backissue/index_backissue.html.

Aoki, E., M. Imashiro, S. Kato, and Y. Wakuda. 2000. A History of Japanese Railways 1872-1999. East Japan Railway Culture Foundation.

Arisue, T. and E. Aoki. 1970. Japanese cities: A geographical approach. Special publication (Nihon Chiri Gakkai), no. 2, pp. 191-200. Association of Japanese Geographers.

Asano, M. 1998. Japanese urban environment. pp. 252-264. Elsevier.

Association of Japanese Private Railways. 2007. Profile of the 16 major private railways (大手 16 社紹介). URL http://www.mintetsu.or.jp/corporate/companys/tokyu/ index.html.

Beans-Coop. 2009. Real estate market by station (駅別土地 相場). URL http://beans-coop.jp/market_tochi_station. html.
Bernick, M. and R. Cervero. 1996. Transit Villages for the 21st Century. McGraw-Hill.

Cervero, R. 1998. The Transit Metropolis: A Global Inquiry. Island Press.

City Mayors Statistics. 2005. The 150 richest cities in the world by GDP in 2005. URL http://www.citymayors. $\mathrm{com} /$ statistics/richest-cities-2005.html.

City of Yokohama Urban Development Bureau. 1998. Overview of the results of the previous (1998) person trip survey (前回(平成 10 年)のパーソントリップ調査 の結果概要). URL http://www.city.yokohama.jp/me/ toshi/kikaku/pt/h10_data/.

Colliers International. 2008. The ten most expensive places to park. URL http://www.moneyhospital.co.uk/blog/post/ the-10-most-expensive-places-to-park.

Dittmar, H. and G. Ohland, eds. 2004. The New Transit Town: Best Practices in Transit-oriented Development. Island Press.

Fujita, K. and R. C. Hill, eds. 1993. Japanese Cities in the World Economy. Temple University Press.

Fukuoka International Association. 2006. Japanese driver's licenses. URL http://www.rainbowfia.or.jp/living/e/14. html.

Goo Housing and Real Estate. 2008. Tama Plaza station information (たまプラーザ駅の情報). URL http://house. goo.ne.jp/chiiki/town/detail/2324150/index.html.

Hartgen, D., G. Ingalls, and T. Owens. 1993. Public Fear of Crime and its Role in Public Transit Use. Center for Interdisciplinary Transportation Studies, University of North Carolina.

Haseko Urbest Inc. 2007. 2007 ranking of most desirable towns (stations) (住んでみたい街 (駅) 2007). URL http: //www.haseko-urbest.com/press/pdf/20071126.pdf.

Home's Club. 2007. Tokyoites choose the most desirable towns - 2007 (東京都民が選ぶ住みたい街 2007). URL http://homesclub.next-group.jp/research/research/ 2007/post_43.php.

Hosono, T. 2004. Tokyo number one, Kyoto number two for condominium parking charges (分譲マンション駐車 場料金、1 位東京 2 位は京都). URL http://sumai. nikkei.co.jp/know/rank/index2004081905277d1.html.

Ieda, H. 1995. Commuter railways: Can congestion be relieved? Japan Railway \& Transport Review, 4:8-15.

Japan Road Association. 2005. World road statistics (世界 の道路統計). URL http://www.road.or.jp/dl/statistics. html.

Japanese Ministry of Land, Infrastructure, Transport and Tourism. 1999. Movement of people in cities (都市にお ける人の動き). Technical report, Railway Bureau of the 
Ministry of Land, Infrastructure. URL http://www1.ibs. or.jp/cityplanning-info/zpt/zptno2.pdf.

Japanese Ministry of Land, Infrastructure, Transport and Tourism. 2002. Motor vehicle inspection and registration guide - Q\&A (自動車検査・登録ガイド・Q\&A). URL http://www.mlit.go.jp/jidosha/kensatoroku/question/ index.htm.

Japanese Ministry of Land, Infrastructure, Transport and Tourism. 2005a. Metropolitan area transportation census (平成 17 年大都市交通センサス). URL http://www. mlit.go.jp/sogoseisaku/kotu_census10/17siryou.html.

Japanese Ministry of Land, Infrastructure, Transport and Tourism. 2005b. Survey of regional flow of passengers and freight. URL http://toukei.mlit.go.jp/17/flow/index.pdf. Jones, M. 1983. Working paper no. 75: Passenger transport planning, management, and policy in japan. In Proceedings of conference held at Wolfson College, Oxford 1983, Working paper (Oxford Polytechnic. Dept. of Town Planning).

Kato, S. 1996. Development of large cities and progress in railway transportation. Japan Railway \& Transport Review, $4(9): 44-48$.

Kawasaki, K. 1993. Suburban culture is created by private railways: Jiyugaoka and along Tokyu rail lines (郊外文化は私 鉄がつくる：自由が丘と東急沿線)，Tokyojin，74(11): $48-51$.

Keiei Jōhō Center. 1971. Tokyu Group's Development Strategy: An In-depth Analysis of Tokyu's Attempt at Developing Urban Industry (東急グループのデベロッパー戦略： 都市産業へ挑戦するデベロッパー東急を徹底的に 分析 (MIC戦略シリーズ第 4 弾), volume 4 of $M I C$ strategy series. MIC.

Kiriyama, H. 1997. An opinionated investigation of Tokyu Dentetsu (東急電鉄の独断的研究). Tokyojin, 78(10): 56-65.

Mieszkowski, K. 2008. Who says Americans won't ride mass transit? Salon.com. URL http://www.salon.com/env/ feature/2008/10/23/mass transit america/.

Miyata, M. 1995. Tokyu. Tokyu Hoikusha Books.

Mizutani, F. 1994. Japanese Urban Railways: A Private-public Comparison. Athenaeum Press Ltd.

Morichi, S. 2000. Socioeconomic characteristics, land use, and travel patterns in Tokyo Metropolitan Area. In M. Bondada, ed., Urban public transportation systems: Implementing efficient urban transit systems and enhancing transit usage, pp. 610-621.

MTR Corporation. 2008. Summary financial report 2007. URL http://www.mtr.com.hk/eng/investrelation/ 2007srpt_e/E206.pdf.
Nagata, K. 2008. A highway system that never exacts toll. URL http://search.japantimes.co.jp/cgi-bin/ nn20081216il.html.

Nakamura, S. 2010. Population density in Central Tokyo. URL http://blogs.yahoo.co.jp/shohei_tokyo_ 1980/32287741.html.

Oshima, K. 1996. Denenchofu: Building the garden city in Japan. Journal of the Society of Architectural Historians, 55(2):140-151. doi: 10.2307/991116.

Railway Town Development Conference. 2004. What Should Be Done? The Future of Railways: To Revitalize Communities (どうする? 鉄道の未来：地域を活性化する ため). Tokyo: Ryokufu Shuppan.

S-Park. 2008. Tokyo parking information site (都内駐車場 案内サイト). URL http://www.s-park.jp/.

Shoji, K. 2001. Lessons from Japanese experiences of roles of public and private sectors in urban transport. Japan Railway \& Transport Review, 29:12-19.

Statistics Canada. 2008. Canada's population estimates: Third quarter 2008. URL http://www.statcan.gc.ca/ daily-quotidien/081219/dq081219b-eng.htm.

Tamapura Scope. 2007. Study of Tama Plaza's walking sphere for the “Beautiful Forest” new town (たまプラーザ徒歩 圏の新しい街“美しの森”大研究). URL http://www. tamapla.jp/wadai/utsukusinomori.html.

Tokyo Metropolitan Government. 2009. Estimate of Tokyo's population for 2009. URL http://www.toukei.metro. tokyo.jp/jsuikei/2009/js090f0000.pdf.

Tokyu Corporation. 2007. 2007/2008 Tokyu Corporation (2007/2008 東急電鉄). Annual report.

Tokyu Corporation. 2011. Timetable by station (各駅時刻 表). URL http://www.Tokyu.co.jp/railway/menu/jikoku. html.

Transportation Research Board. 2003. Transit capacity and quality of service manual, 2 nd edition. TCRP Report 100, Transportation Research Board.

Transportation Research Board. 2005. Transit-oriented development: Developing a strategy to measure success. NCHRP Research Results Digest 294, Transportation Research Board.

United Nations. 2007. World urbanization prospects: The 2007 revision population database. URL http://esa.un. org/unup/p2k0data.asp.

Victoria Transport Policy Institute. 2006. Fuel price, consumption, travel and risk. URL http://www.vtpi.org/tdm/ tdm80.htm.

Vuchic, V. 2005. Urban Transit: Operations, Planning, and Economics. John Wiley \& Sons. 